\title{
Modelling the Disruptive Innovations
}

\author{
Leonid Kharlov
}

Freelancer; leonid.kharlov@gmail.com

\begin{abstract}
Horse carriages, film cameras, and traditional encyclopedia were dethroned by the once bizarre cars, digital cameras, and online resources, respectively. Although such major shifts were happening for at least one hundred years by now, the Theory of Disruptive Innovations was designed only in the late nineties by a prominent academic and business consultant Clayton Christensen. So, the main questions of my paper are how do disruptive innovations proceed and what are the factors causing the disruption? The existing literature provides a substantial critique of Christensen's theory and taken this into account. I propose that the disruptions usually succeed due to the random factors or the ones not directly connected to Disruption Theory and unfold favourably for incumbents irrespectively of their strategical choices.

Keywords: Theory of Disruptive Innovations; disruptive business; disruptive character of innovations

JEL Classification: M31, M13, 032, 033

(c) Leonid Kharlov, 2020
\end{abstract}

\section{Literature Review}

The Theory of Disruptive Innovations was designed only in the late nineties by a prominent academic and business consultant Clayton Christensen. Now, this popular management framework is used extensively in various industries both by the executives of small enterprises and multinational corporations. However, "despite the theory's widespread $<\ldots>$ appeal, its essential validity and generalizability have been seldom tested in the academic literature" (King \& Baatartogtokh, 2015, p. 78).

The primary source I want to rely on in this paper is research conducted by Clayton Christensen. It has laid a foundation for the disruptive innovation theory, which, in a word, points out that "the technological changes that damage established companies are usually not radically new or [technologicaly] difficult" (Christensen \& Bower, 1995). According to Christensen, disruptive innovations (1) initially offer new performance attributes that are not valued by existing customers, (2) start from the low-performance and low-price sectors of the market and attract non-customers, and (3) improve performance attributes valued by existing customers "at such a rapid pace that [they] can later invade established markets" and displace incumbents (Christensen \& Bower, 1995). The performance curve of the market is sustained, and even the disruptors usually do not change it. So, there are low-demand, middle-demand, and high-demand customers, and incumbent companies are better off focusing on the most lucrative clients - high-demand ones. When new disruptive business emerges, incumbents often disregard it being too niche and end up losing the share. The plenty of examples of disruptive businesses, as Christensen writes, can be found in the technological industry and a hard disk sector particularly (Christensen \& Bower, 1995). Telephony, online encyclopedia, transistors, and streaming are the disruptors as well - everything in this list has started as an inferior competitor with peculiar features but ended up triumphant; these technologies have already taken over their markets entirely or are in the process of doing so. However, despite the immense both theoretical and practical acceptance of the theory, there are some contesters of it.

In his study, professor of strategy and entrepreneurship in London Business school and one of the famous experts on strategy and innovation Constantinos Markides (2006) insists that although technological, business-model and new-to-the-world product innovations are rendered as one in disruptive innovations theory because of similarities, the distinction should be made since these three types of innovations 
"produce different kinds of markets and have different managerial implications" (Markides, 2006, p.19). For example, unlike disruptive technological innovations, business-model ones do not necessarily grow to dominate the market and it is not an oversight of the managers that they do not accept them - they mostly do not make sense for established companies (Markides, 2006, p. 22). For example, "budget, no-frills flying as a way of business has grown phenomenally since 1995 but has captured no more than 20 per cent of the total market [by 2005]" (Markides, 2006, p. 21). Radical product innovations, in turn, are disruptive both for companies and for customers because (1) they "disturb prevailing consumer habits and behaviors in a major way" (Markides, 2006, p. 22 ), and (2) "the markets they create undermine the competences and complementary assets on which existing competitors have built their success" (Markides, 2006, p. 22). Furthermore, such innovations are not usually driven by demand but rather pushed by "those responsible for developing new technologies” (Markides, 2006, p. 22). Such disruptors, as Markides writes, frequently lose their share excessively developing the performance of a product and hence heightening its price. Thus, only technological enthusiasts and early adopters are pioneers' clients, while incumbents come to the market later with goodenough and cheap-enough products appealing to the mass market. So, Markides provides insight that disruptive innovations may have similar trajectories but present different outcomes and inherent features.

Proceeding with the critique of Christensen and Raynor's research, Andrew A. King and Baljir Baatartogtokh write that "the theory is so widely accepted that its predictive power is rarely questioned" (King \& Baatartogtokh, 2015, p. 78). Thus, contrary to Christensen, "approximately one-third of incumbents were not displaced by new technology” (King \& Baatartogtokh, 2015, p. 81) -- "most managers respond effectively to potentially disruptive threats" (King \& Baatartogtokh, 2015, p. 78). Furthermore, the incumbents can sometimes fail because of major foresight or other semirandom events, but not their technical inferiority; "A few early sales can initiate a feedback loop of network advantage that tips all customers to one supplier" (King \& Baatartogtokh, 2015, p. 85). It was the case with Apple's MacOS and Microsoft
DOS when the last one acquired IBM's favour and was thought of as a system that customers would adopt. Also, the researchers describe the "gold rush" that takes place after the creation of new infrastructure and/or change of demographics that is to a certain extent similar to the process of disruptive product innovations that Markides describes. When the change in the market happens, "sometimes incumbents are simply outnumbered by the sheer quantity of new competitors.... Because of their numbers ... new entrants [are] able to cover more ground in the aggregate. The laws of probability thus said that in most cases, new entrants would stake the best claims and be the biggest winners" (King \& Baatartogtokh, 2015, p. 85). But it is not clear whether this conclusion is contradictory to the one of Markides. On the one hand, the outcomes of these two seemingly similar processes are different (victory of newcomers in the last case and incumbents in the former), but on the other, King and Baatartogtokh's example of "gold rush" is not said to be disruptive for consumers and thus may be another type of innovation. However, the significant implication is present in both sources - the rate of innovations and the number of competitors are at their highest when novelty is introduced.

To sum up, the findings of C. Markides, A. King, and B. Baatartogtokh that complement the basic Theory of Disruptive Innovations and that are crucial for my research are (1) there is some randomness in the final power balance of competitors; (2) about a third of incumbents survive disruptions; (3) rate of innovations and quantity of competitors are at their highest when novelty is introduced.

\section{Research Method}

To investigate the plausibility of the disruption processes described in the literature, I decided to create an agent-oriented model in NetLogo 6.1.1. Besides the basic theory of Christensen, my model adopts the concepts of Markides, King and Baatartogtokh; namely, the disruptive character of innovations both for users and producers, and the decreasing rate of innovations after introduction.

To recreate the trajectory of technological development Christensen described in his papers, I've designed two breeds of turtles - users and developers. 
The users usually have distributed demands or, in other words, preferences which increase by a certain per cent every tick if the market performance is on par with user preferences and decrease if the preferences greatly exceed the performance. The formula of preferences:

$$
p_{t}=p_{t-1} *\left(a *(1+x)+(1-a)^{2} *(1-x)\right),
$$

where:

$p_{t}$ - preference of user at tick $t$;

$a$ - dummy variable that shows whether the performance of the best product is greater than the preferences of the least demanding user

$x$ - the share by which preferences change.

Then, there is a budget that is positively correlated with the preferences by $95 \%$ initially. To justify such a high correlation, I assume that the budget is mentally accounted for things users value; its computation goes as follows:

$$
b_{t}=b_{t-1} *(1+x) \text {, }
$$

where:

$b_{t}-$ a budget of the user at tick $t$;

$x$ - share by which budget of a user grows per tick

At last, users possess conservatism which represents how long they are bound to stay with the product they once chose. The developers, in turn, have one distinct variable - stamina, which is analogous to conservatism. Every user or developer is attached to a product.

Products are the patches that users and developers choose. They have cumulative funding - the sum of users' budgets on the patch is added to it every tick, but the salary for the developers is subtracted; if the product is unpopular with users or developers, its funding drops by a certain per cent every tick (this figure is five per cent in my model).

The equation for computation funding is:

$$
F_{t}=F_{t-1}-a *\left(n_{d} * \bar{b}-\sum_{i=0}^{n_{u}} b_{i}\right)-(1-a)^{2} * F_{t-1} * d,
$$

where:

$F_{t}$ - funding of product at tick $t$;

$n_{d}$ - number of developers on patch;

$n_{u}$ - number of users on patch;

$b$ - budget of the user; $\bar{b}$ - mean budget of users;

$a$-dummy variable that displays whether the product is popular among users and developers;

$d$-decrease-share of funding per tick.

Then, every product has productivity - the rate of developers' contribution towards the enhancement of the product's performance; the more performance exceeds average users' preferences, the smaller the productivity. This concept is retrieved from the observations of C. Markides I mentioned in the Literature Review. Like funding, the performance of a product degrades if the product is unpopular among users and developers. Performance equation is below:

$$
P_{t}=P_{t-1}+n_{d} * e-a * o,
$$

where:

$P_{t}-$ performance of the product at tick $t$;

$n_{d}$ - number of developers on patch;

$a$-dummy variable that displays whether the product is popular among users and developers;

$o$ - obsolescence rate (constant)

$e$ - productivity rate of the patch.

To choose the product, users and developers calculate the utility functions of patches and pick the one with the highest output. The assumptions that are behind this formula are that (1) the users either benefit from the popularity of a product or value it more if it is popular among people; (2) users appreciate that developers support the product; (3) users do not like the lack or excess of performance.

The utility function of a user for product $\mathrm{x}$ :

$$
U_{x}=\frac{P}{b} *\left(1+k_{u}\right) *\left(1+k_{d}\right)-(P-p)^{2},
$$

where:

$U_{x}$ - the utility function of product $x$;

$P$ - performance of product $x$;

$b$ - budget of the user;

$k_{u}$ - coefficient of product $x$ popularity among users;

$k_{d}$ - coefficient of product $x$ popularity among developers;

$p$ - preference of the user.

The utility function of a developer for product $\mathrm{x}$ :

$$
U_{x}=F^{*}\left(1+k_{u}\right),
$$


where:

$U_{x}-$ utility function of product $x$;

$F$ - funding of product $x$;

$k_{u}$ - coefficient of product $x$ popularity among users

To simulate the disruption in my model, I create $n$ developers and $m$ users in an unpopular patch and increase developers' stamina to let them advance the product and not flee. Funding for a disruptor initially equals mean product funding. In ideal circumstances, the performance curve of my disruptors replicates the one described by A. Christensen, and they should eventually "invade established markets"; the productivity coefficients of the early lifecycle let them do it. There is also a feature of manual investment into the disruptor in the model.

\section{Findings}

The results of the simulation suggest that the success of disruptions depends greatly on the moment they happen. When the responsecurves of users start to go down, the average share of attracted users appears to be greater than in the case of disruptions launched in a steady growth period. Thus, in the latter case, the chance of the product's survival decreases considerably, and even the additional investments or boosted productivity could not help it most of the time I launched the model. Rapid exponential fall of the response rates that happen after the long stagnation is not the best time for disruptions too, since, on such occasion, users usually quit the disrupting product even before the developers. At this stage, it is hard for new competitors to attract big enough funding and thus, new developers and gain performance.

Furthermore, according to my observations, the full-blown disruptions of major incumbents are extremely rare in given circumstances. Indeed, disruptors that were able to stay on the market poach the users of other products. Still, developers usually remain loyal to their patch due to accumulated funding and big userbase and sustain the product performance. The initial increased number of users in disruptor patch do net help attracting users of other demand-levels and developers from different patches as well. In my launches, even multiple disruptors introduced at the same time have not destroyed the incumbents ever; they have been only making their share of the market smaller.

Another observation is that due to the feedback loops, from run to run predispositions of a market are different; sometimes the response rates are the highest for the most demanding customers, and sometimes middle-range or low-tier users are the most satisfied. Anyhow, in the vast majority of cases, disruptions cannot change the response trends - all indicators recover shortly after the appearance of a new competitor. Moreover, even multiple disruptors introduced at the same time make the response curves less stable, but do not change their trajectory (at least, the effect is not immediate).

\section{Discussion}

My findings are more in line with the research of A. King rather than the one of A. Christensen - the disruptions in the model are rare and do not deserve the attention of incumbents most of the time since the strategy has proven to be irrelevant in fighting them. Due to the incumbents' stability, and disruptors' comparatively small starter userbase, its low solvency, a small number of developers, and thus low attractiveness for new users, disruptors mostly either are self-eliminated or end up secondary to incumbents they were supposed to disrupt in my model.

A perceived "disruption" in the real world can happen due to the factors we do not see, and thus inherently conform the mechanisms completely different from the one of Disruptive Innovations Theory. As it is said in the A. King's study, "a majority of the 77 cases [of disruption] were found to include different motivating forces or displayed unpredicted outcomes. Among them were cases involving legacy costs, the effect of numerous competitors, changing economies of scale, and shifting social conditions" (King \& Baatartogtokh, 2015 , p. 79). This complexity can even be traced in my model, where some of these factors were at play. For example, sometimes the "disruptors" appeared right before the collapse of a popular product and merely inherited its userbase; sometimes a few unsatisfied users started the feedback loop leading to the product's growth, and sometimes a new disruptor indirectly helped the old one to gain userbase merely raising its comparative popularity coefficient. 


\section{Conclusions}

So, the Theory of Disruptive Innovations may be a guiding light for some entrepreneurs, and the examples that conform to this framework may be found in abundance. Still, we cannot be sure that the survivorship bias is avoided in case studies of such a sort. The Theory of Disruptive Innovations can be regarded as a "good reminder of potential pitfalls <...> but in no way does it predict what most companies will do" (King \& Baatartogtokh, 2015, p. 86). My model echoes these warnings and shows that even with all the conditions provided, successful disruptions are rare and happen mostly due to the random factors; even intensive investments or a big initial userbase can sometimes do no good in such situations.

\section{Future Scope}

In future research, I plan to work closely with the concepts C. Markides introduced in his paper. The division of disruptive innovations by their managerial implications and adding a set of strategical responses for incumbents may add another layer of useful complexity to my model and thus can let me be more confident about the plausibility of the results.

Furthermore, in the future, I want to supplement this paper with the statistics on the frequency of disruptions in the model and provide the data on the statistical significance of my conclusions.

\section{References}

Christensen, C. M., Bower, J. L. (1995, February). Disruptive Technologies: Catching the Wave. Retrieved from https://hbr.org/1995/01/disruptive-technologies-catching-the-wave.

Markides, C. (2006). Disruptive Innovation: In Need of Better Theory. Journal of Product Innovation Management, 23(1), 19-25. doi: 10.1111/j.1540-5885.2005.00177.x.

King, A. A., Baatartogtokh, B. (2015). How Useful Is the Theory of Disruptive Innovation? MIT Sloan Management Review, 57(1), 77-90. Retrieved from https://sloanreview.mit.edu.

Моделирование разрушительных инноваций

Леонид Харлов

Аннотация. Конные экипажи, кинокамеры и традиционная энциклопедия были свергнуты с «престола» некогда причудливыми автомобилями, цифровыми камерами и интернет-ресурсами. Хотя такие серьезные сдвиги происходят уже по меньшей мере сто лет, теория разрушительных инноваций была разработана только в конце 90-х годов видным ученым и бизнес-консультантом Клейтоном Кристенсеном. В статье представлены результаты поиска ответа на вопрос: как происходят разрушительные инновации и каковы факторы, вызывающие их разрушение? Существующая литература содержит основательную критику теории Кристенсена. Автор предполагает, что деструкция обычно достигает успеха благодаря случайным факторам или тем, которые непосредственно не связаны с теорией деструкции, и разворачиваются благоприятно для действующих лиц независимо от их стратегического выбора. Ключевые слова: теория деструктивных инноваций; деструктивный бизнес; деструктивный характер инноваций 